\title{
Investigation of the character and impact of tropical cyclone Yaas: a study over coastal districts of West Bengal, India
}

\author{
Swapan Paul ${ }^{1}$ (D) . Swetangee Chowdhury ${ }^{1}$
}

Received: 7 June 2021 / Revised: 24 September 2021 / Accepted: 24 September 2021 / Published online: 30 September 2021

(c) The Author(s), under exclusive licence to Springer Nature Switzerland AG 2021

\begin{abstract}
Tropical cyclones have become more frequent as a result of climate change and the associated temperature rise in the ocean surface, wreaking havoc on both natural and man-made elements. The most recent storm, Yaas, has had a wide-spread impact on coastal areas, with high-intensity wind, rainfall, and, most significantly, inundation in Odisha and West Bengal coastal region. Yaas formed over east central Bay of Bengal as a depression and gradually intensified to VSCS and finally made landfall near Balasore of Odisha coast, with a wind speed of $130-140 \mathrm{~km} / \mathrm{h}$. on 26th May, 2021. The present study is, therefore, aimed to characterize the cyclone Yaas and to investigate the expansion of cyclonic inundation in different sector of coastal West Bengal. Several space-borne data sets were employed in this study, including GPM data to illustrate precipitation variability, Sentinel-1 images for inundation mapping, and Sentinel-2 data to determine MNDWI for both pre- and post-cyclonic periods. The results show that during this cyclonic period, hundreds of $\mathrm{km}^{2}$ of land in West Bengal, including blocks of South 24 parganas, East Medinipur and North 24 parganas such as Sagar $\left(37.10 \mathrm{~km}^{2}\right)$, Namkhana $\left(78.12 \mathrm{~km}^{2}\right)$, Pathar Pratima $\left(58.74 \mathrm{~km}^{2}\right)$, Ramnagar I $\left(15.24 \mathrm{~km}^{2}\right)$ and II $\left(19.62 \mathrm{~km}^{2}\right)$, Khejuri $\left(22.27 \mathrm{~km}^{2}\right)$, and other blocks were inundated by cyclonic surge and about a total of $1195 \mathrm{~mm}$ of rainfall. Eventually, people have lost their homes, properties have damaged, and many agricultural fields have become barren by salt water accumulation.
\end{abstract}

Keywords Tropical cyclone $\cdot$ Inundation mapping $\cdot$ SAR-C $\cdot$ MNDWI $\cdot$ Cyclone Yaas

\section{Introduction}

Coastal zones are highly sensitive as it is exposed to different coastal hazard such as erosion, cyclonic storm related inundation and sea level rise (Ramsay et al. 2012). Tropical cyclones, which have been the deadliest coastal hazard on the earth for the previous two centuries, produce devastating wind, storm surges, and torrential rainfall, wreaking havoc on coastal areas (Qi and Du 2018; Kunze 2021). International Workshop on Tropical Cyclone States that the intensity of tropical cyclones has increased in the previous 35 years as a consequence of ongoing warming of sea surface water, which has been above the threshold temperature

Swapan Paul

spaul5481@gmail.com

Swetangee Chowdhury

swetangeechowdhury@gmail.com

1 Department of Geography, West Bengal State University, Malikapur, Berunanpukuria, Barasat, Kolkata, West Bengal 700126, India of $28^{\circ} \mathrm{C}$ as a result of climate change (Dasgupta et al. 2010; Bielli et al. 2021). The Bay of Bengal provides a perfect breeding site for cyclogenesis, accounting for $6-10 \%$ of worldwide cyclone generation and putting millions of people at risk (Hossain et al. 2019). In the case of the Indian subcontinent, most tropical cyclones originate in the Bay of Bengal with a frequency of about 4-5 times in a year (Bhaskaran et al. 2020) and make landfall on east coast of India, with Odisha experiencing the highest number of cyclone strikes, followed by Andhra Pradesh, West Bengal, and Tamilnadu (Sahoo and Bhaskaran 2017). The northward converging shapes of Bay of Bengal offer an ideal platform for surging storms, which are especially intense in the West Bengal-Odisha Coast owing to its extensive shallow continental shelf, resulting in water level rise and rapid flooding (MoES 2021). Cyclone induced coastal inundation is, therefore, a major contributor to loss of lives which is particularly in less developed countries of tropical and subtropical region (Royer et al. 1998; Resio and Irish 2017). Coastal West Bengal in this context, is highly susceptible due to its exposed communities, particularly densely populated rural 
settlements (Samanta 1997; DasGupta and Shaw 2015; Ghosh and Ghosal 2021), which have witnessed several storm surges events that have asserted lives and livelihoods, washed away many protective embankments, and inundated significant coastal regions with saline waters (Brammer 2014; Saha 2015; Gayathri et al. 2016) in the past. Moreover, the high tidal amplitude and complex coastline geometry of the world largest deltaic system of Ganga-BrahmaputraMeghna (GBM) delta, comprising of numerous drainages, tidal creek and mudflats have made the region more sensitive (Gayathri et al. 2015; Ali et al. 2019). As such, the 1737 and 1970 Cyclone in India and Bangladesh were the deadliest tropical cyclone, combinedly killed approximately 300,000 people, due to its highly congested coastal population and limited technological advancement (Needham et al. 2015). Also, the 2009 Aila cyclone, which was the most devastating pre-monsoon cyclone in Bay of Bengal during last 20 years, caused massive inundation in the Sundarbans region of West Bengal and Bangladesh (Palit and Batabyal 2010; Debnath 2013), where the surge amplitude in the rivers Matla, Bidyadhari, and Garal reached nearly $4 \mathrm{~m}$ and the flood extent was about $1000 \mathrm{~m}$ from the river banks (Deb et al. 2011; Gayathri et al. 2016). Just one year ago, Amphan in 2020, the strongest super cyclone ever recorded in the Bay of Bengal after the 1999 Odisha cyclone (Mishra and Vanganuru 2020; Halder et al. 2021), swamped around $12.3 \%$ of deltaic West Bengal, while not being connected with the greatest storm surges like Aila, but with tremendous wind speeds and torrential rains (Das et al. 2020).

Remote sensing has previously been proven to be a useful technique in gaining a better knowledge of coastal storm dynamics in three phases: before, during, and after landfall. Data from spaceborne remote sensing satellites such as Quick SCAT, MODIS (Moderate resolution Imaging Spectroradiometer), and Meteosat has been used in many studies to monitor ocean-atmospheric processes as well as flood propensity in coastal areas (Tralli et al. 2005). Moreover, the introduction of medium to high resolution SAR (Synthetic Aperture Radar) sensor in 2010s, having the potentiality of penetrating clouds and forest canopy to detect standing water, has improved the accuracy of the observation (Schumann and Moller 2015). Therefore, utilizing a SAR sensor to monitor flood extent by discriminating between flooded and dry areas (Klemas 2009, 2015) overcomes the limitation of a ground-based classical hydrological monitoring system (Uddin et al. 2019).

Recently, coastal West Bengal was hit by another cyclone, Yaas, which had a wind velocity of even more than $120 \mathrm{~km} / \mathrm{h}$ between May 22 and May 28, 2021 (IMD 2021a). The most severe impact of this cyclone was felt in Odisha and West Bengal due to cyclonic wind, storm surge-induced floods, and the crumbling of mud houses, among other things. Consequently, the devastating power of this cyclone can also be estimated by comparing it with the others. The current research, is therefore, intended to characterize Cyclone Yaas and its first effects on coastal West Bengal using primarily remotely sensed data.

\section{Database and methodology}

\section{Study area}

The $325 \mathrm{~km}$ long (including islands) stretch of coastal West Bengal between the Cuspate Delta of the Subarnarekha Estuary in the west and the GBM delta-originating Harinbhanga river in the east, extending from $21^{\circ} 36^{\prime} 36.91^{\prime \prime} \mathrm{N}$ and $87^{\circ}$ $29^{\prime} 1.94^{\prime \prime} \mathrm{E}$ to $21^{\circ} 41^{\prime} 54.81^{\prime \prime} \mathrm{N}$ and $89^{\circ} 6^{\prime} 24.37^{\prime \prime} \mathrm{E}$, is the most affected region in terms of coastal inundation due to the presence of a complex network of tidal fed channels and inlet system, extending much interior of the land surface a well as its high tidal range. Coastal West Bengal can thus be divided into two distinct coastal environments: (a) mesotidal western sector consisting of the Digha-Sankarpur-Junput coastal plain in East Medinipur district, with a tidal range of 2-4 m, and (b) macrotidal eastern sector consisting of the Hugli estuary and Sundarban regions in South and North 24 Parganas district, with a tidal range greater than $4 \mathrm{~m}$ (IIT 2006). The $60 \mathrm{~km}$ long Medinipur coastal part, extending from the Kolaghat town on the right banks of the Rupnarayan river to Digha in Subarnarekha deltaic zone, makes up about $27 \%$ of total coastline of West Bengal, including major coastal towns like Haldia, Khejuri, Junput, Baguran Jalpai, Dadanpatrabar, Contai, Tajpur and so on. Sundarban Part, on the other hand, encompass a considerable portion of the eastern coastal areas, including blocks like Sagar, Kakdwip, Namkhana, Mathurapur, Patharpratima, Kultali, Basanti, Gosaba, Sandeshkhali, and Hingalganj in the North and South 24 Parganas.

The generation of tropical cyclone in and around the Bay of Bengal and its intensive devastating capacity in the pre-monsoon and post-monsoon months, have greatly increased due to the contemporary global climate change and resultant global warming (Bhardwaj et al. 2019; Li et al. 2020; Bhardwaj and Singh 2021). Accordingly, due to the position of West Bengal along the northern tip of Bay of Bengal, it ranks first among the cyclone prone states in India (Ahammed and Pandey 2021), having four (South 24 Parganas, Medinipur, Kolkata, North 24 Parganas) of the fourteen most cyclone-prone districts in the country (Rehman et al. 2020). As such, a total 29 cyclones, including 16 severe cyclones, have made landfall in the South 24 parganas district, while Medinipur district faces a total of 22 cyclones including 12 severe cyclones so far during period 1891-2017 (IMD 2021b). Furthermore, according to the West Bengal Vulnerability Atlas (1997), this area has 
a high possibility of experiencing a maximum storm surge height of 12-12.5 m owing to cyclonic winds, since it has already experienced such destructive cyclonic flooding during the super cyclone of 1737 (Sharma 1996). Eventually, the hazard proneness factor has been graded as very high (7.1-10) for all the coastal districts of West Bengal (BMTPC 2006; Mohapatra et al. 2012), and the situation is becoming increasingly dangerous for the poor inhabitants of this area (Fig. 1).

\section{Data collection}

A set of data and photographic evidences were obtained from various primary and secondary sources to provide a concise insight into the character as well as the initial effect of cyclone Yaas. Accordingly, cyclonic data related to cyclone trajectory, most affected area, wind field, pressure condition, etc., were obtained from the daily bulletin (BOB/02/2021, dated 27-05-2021) of Indian Meteorological Department (IMD) for the period 21st May-28th May, 2021. Besides, a set of Global Precipitation Measurement (GPM) data in terms of total accumulated rainfall were collected from the distributed active archive center (DAAC) to interpret the precipitation variability during the cyclone operative time. Side by side, a range of NOAA 20/VIIRS image were also collected to visualize the generation, growth, and track of the storm (https://worldview.earthdata.nasa.gov). Also, a set of all-weather and day-or-night friendly Synthetic Aperture Radar based high resolution (5 m) level-1 Ground Range Detected (GRD) sentinel-1 satellite images, with both VV (Vertical Transmit and Vertical Received) and VH (Vertical Transmit and Horizontal Received) polarization, were acquired from the European Space Agency (ESA) to differentiate between the pre-Yaas and post-Yaas condition. In addition, two moderately high resolution $(10 \mathrm{~m})$ multispectral satellite images were collected for the before and after storm conditions. Also, a Shuttle Radar Topography Mission (SRTM)-based Digital Elevation model (DEM) with a resolution of $30 \mathrm{~m}$ at ground was also collected from the United States Geological Survey (USGS) aimed to use in the preprocessing of Radar images. Table 1 contains a complete summary of the obtained space-borne data.

\section{Image processing and analysis}

To identify the storm induced flooding, two multi-dated SAR images were used to differentiate between actual surface waterbody and cyclonic water accumulation. However, before the ultimate merging of the images, a sequential preprocessing such as subset creation, multilooking, radiometric calibration, speckle filtering, geometric terrain correction, reprojection as well as linear-to-backscattering coefficient decibel scaling $(\mathrm{dB})$ transformation, and data export, were implemented using ESA's Sentinel Application Platform (SNAP), as discussed in the following sections.

\section{Subset creation and multilooking}

After creation of the subset to extract the study area from the images, multilooking operation was employed in SNAP 7.0. Usually, raw SAR images seem speckled due to intrinsic speckle noise (Qiu et al. 2004). To decrease this natural speckled effect, several scenes are incoherently blended as though they belonged to distinct appearances of the same location (Engelbrecht et al. 2017). Multilooking was thus accomplished in this study based on the source bands, and assigned GR square pixels, number of range and azimuth looks, and output intensity.

\section{Radiometric calibration}

In the case of Radiometric calibration, backscatter intensity received by the sensor is transformed to a standardized measure called the normalized radar cross section (Sigma0) (Barzycka et al. 2019; Zhang et al. 2020), which takes into account the global occurrence angle of the scenes and other sensor-specific features (Torres et al. 2012). To do this, the application output scaling applied by the processor must be undone and the desired scaling must be applied. The radiometric calibration can, therefore, be applied by following the Eq. (1).

$\operatorname{Value}(i)=\frac{\left|D N_{i}\right|^{2}}{A_{i}^{2}}$

where depending on the selected calibration look up tables, Value (i) is one of the $\beta_{i}^{0}, \sigma_{i}^{0}$, or ordinal $D N_{i}^{0}$; and $A_{i}$ is the one of the betaNought (i), sigmaNought (i), or DN $(i)$.

However, in this study, the VV polarization of the Sentinel-1A IW GRD product was utilized to calibrate the SAR pictures rather than both the VV and VZ of the GRD products, since so many studies (Twele et al. 2016; Kumar 2017; Mansaray et al. 2017) suggested that the VV polarization of the Sentinel-1A IW GRD product is more appropriate for flood identification.

\section{Geometric terrain correction}

"The Range Doppler Terrain Correction" tool applies the "Range Doppler orthorectification" technique to convert the single 2D raster radar geometry to rectified SAR-C imageries by means of geocoding (Castillo et al. 2017; Saganeiti et al. 2020). As such, terrain geocoding entails correcting for inherent geometric distortions including foreshortening, layover, and shadow with a Digital Elevation Model (DEM). However, SNAP can automatically determine the 

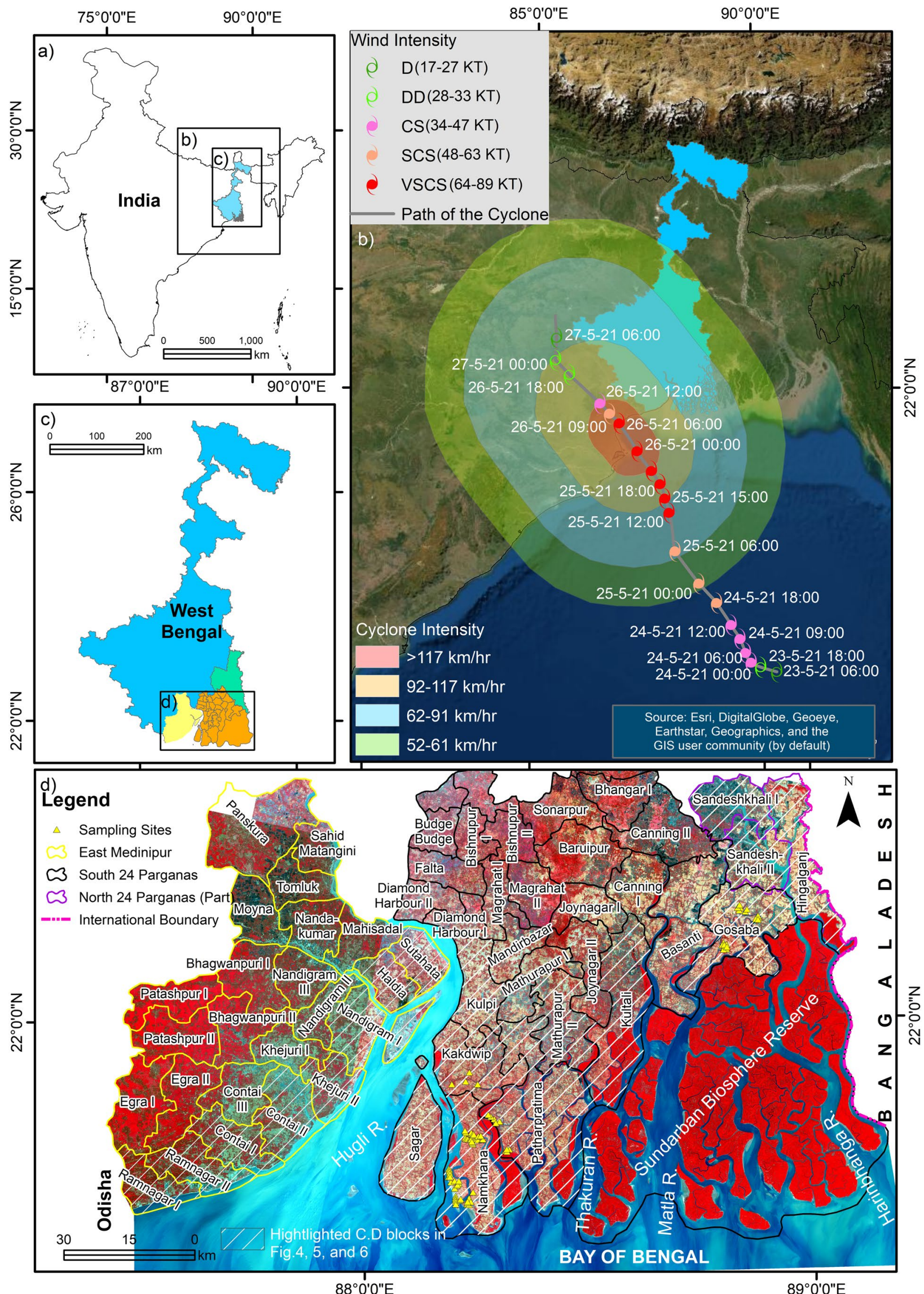
4 Fig. 1 Location of the study area; $\mathbf{a}$ and $\mathbf{c}$ Location of India and West Bengal; $\mathbf{b}$ is showing cyclone trajectory during period May 23May 27, 2021, variability of wind intensity and its influence zone; d coastal West Bengal consisting of East Medinipur, South 24 Parganas, and North 24 Parganas, Source b IMD (2021a), and d Landsat 8 FCC composite (acquired on Feb 22, 2021)

DEM tiles needed and download them automatically from the Joint Research Center FTP (xftp.jrc.it) for the area covered by the image, but a strong internet connection is needed in that case. So, the authors have used the SRTM DEM manually to speed up the processing time. Therefore, the coordinate system was also changed from the Geographic Coordinate System (GCS) to Projected Coordinate System (PCS) (WGS 84 UTM 45N) for the better measurement of flooded area further. A radiometric normalization was also applied to decrease the differences between images in time series based on the approach proposed by Kellndorfer et al. (1998), using Eq. (2).

$\sigma_{\text {NORLM }}^{0}=\sigma_{\text {Ellipsoid }}^{0} \frac{\operatorname{Sin} \vartheta_{\text {DEM }}}{\operatorname{Sin} \vartheta_{\text {Ellipsoid }}}$

where $\vartheta_{D E M}$ is the local incidence angle projected into the range plane and defined as the angle between the incoming radiation vector and the projected surface normal vector into range plane.

In addition, a log function is applied to the terrain corrected radar images to achieve a normal distribution of terrain corrected value of Sigma0, which decodes the pixel values into a logarithmic scale and results in higher contrasts, since bright values are moved towards the mean while dark values are stretched over a wider color range. The formula for conversion from liner to $\mathrm{dB}$ scale is described in Eq. (3).

$\sigma_{d B}^{0}=10 \bullet \log _{10} \bullet \sigma^{0}$

where $\sigma_{\mathrm{dB}}^{0}$ is the backscattering image in $\mathrm{dB}$, and $\sigma^{0}$ is the SigmaNought image.

\section{Inundation mapping and estimation of flood affected population}

Both the processed pre-cyclone and post-cyclone images until geometric correction having both the sigma0 and $\mathrm{dB}$ scale were stack together using co registration tool of SNAP. Thereafter, layer manager tool was used to superimpose the crisis image (post-cyclone) over the archive image (pre-cyclone) aimed to detect the change in water area. In the next step, a RGB composite was prepared based on the stack image, where the $\mathrm{dB}$ archived image was specified as red channel, and $\mathrm{dB}$ crisis image was used for both green and blue channel. The reason behind this is that in the red channel, we will have a high radar response over the flooded areas because these areas will be land. On the other hand, in the case of archive image we do not expect to see the flooded areas and therefore we will have a high backscatter return. Accordingly, flooded areas will have a high response in red channel, but a low response in green and blue channels. Finally, the RGB composite image was exported to ArcGIS 10.6 for further calculation of flooded area.

To obtain a crude idea about the flood affected population, the village level map from the district census handbook was superimposed over the inundation map, and therefore the most affected villages were sorted out. However, obtaining an estimate of the affected population of villages that were fully submerged was rather straightforward, but getting an idea of the affected population of villages that were partially submerged was fairly challenging. In that scenario, a population was estimated using satellite images based on the proportion of the submergence, the location of the submergence, and the spatial pattern of population density. Accordingly, the affected populations of fully submerged and partially submerged areas were combined together to obtain the final figure.

\section{Accuracy assessment of flooded area mapping}

Accuracy assessment refers to the number of pixels in a classified image that is consistent with the reality, explicitly, how many have been accurately classified using the algorithm (Liu et al. 2007; Olofsson et al. 2014). It is very significant for understanding the exactness of the results and use in enforcing various policies. In this study, accuracy assessment of the extracted flood image was carried out using a total number of 85 ground truth data (flooded and not flooded zones were registered using Garmin GPS), obtained from the actual field by the means of random sampling from different section of Patharpratima, Namkhana, and Sagar block. A confusion matrix was used here (flood result is given in rows while reference is shown in column) because of its popularity and simplicity in the ground of remote sensing. The confusion matrix appears to deliver an excellent summary of the two types of thematic error that can occur, namely, underestimation or omission and overestimation or commission. Depending on the information obtained from the contingency table, a number of analytical measures viz. overall accuracy, producer's accuracy, and user's accuracy have been used to calculate the flood extent accuracy from different perspectives. Besides, Kappa statistics of the classified image was also performed along with the overall accuracy to enhance the degree of acceptance of the result. The formula of kappa statistics $K$ is as follows

$k=\frac{N \sum_{i=1}^{r} x i i-\sum_{i=1}^{r} x_{i}+* x_{i}+i}{N^{2}-\sum_{i=1}^{r} x_{i}+* x_{i}+i}$ 
Table 1 Description of collected satellite images for the study

\begin{tabular}{|c|c|c|c|c|c|c|}
\hline Satellite & Sensor & Path/row or scene identity & $\begin{array}{l}\text { Date and time of acquisi- } \\
\text { tion (IST) }\end{array}$ & Cloud cover & $\begin{array}{l}\text { Spatial reso- } \\
\text { lution }\end{array}$ & Source \\
\hline \multirow[t]{2}{*}{ Landsat 8} & \multirow[t]{2}{*}{ OLI and TIRS } & $138 / 45$ & 04-02-2021 10:01:31 & $0.03 \%$ & \multirow[t]{2}{*}{$30 \mathrm{~m}$} & \multirow[t]{2}{*}{ USGS } \\
\hline & & $139 / 45$ & 22-02-2021 10:07:52 & $0 \%$ & & \\
\hline \multirow[t]{2}{*}{ Sentinel 2B } & \multirow[t]{2}{*}{ MSI } & T45QXE & 29-05-2021 10:06:59 & $66.97 \%$ & \multirow[t]{2}{*}{$10 \mathrm{~m}$} & \multirow[t]{2}{*}{ ESA } \\
\hline & & T45QWD & 29-05-2021 10:06:59 & $33.37 \%$ & & \\
\hline \multirow[t]{4}{*}{ Sentinel 1} & \multirow[t]{4}{*}{ SAR-C } & 38095 & 14-05-2021 17:42:36 & - & \multirow[t]{4}{*}{$5 \mathrm{~m}$} & \\
\hline & & & 26-05-2021 17:42:36 & - & & \\
\hline & & 37884 & 14-05-2021 17:42:11 & - & & \\
\hline & & & 26-05-2021 17:42:11 & - & & \\
\hline \multirow[t]{6}{*}{ SRTM } & \multirow[t]{6}{*}{ SAR } & SRTM1N21E087V3 & $11-02-2000$ & - & \multirow[t]{6}{*}{$30 \mathrm{~m}$} & \multirow[t]{6}{*}{ USGS } \\
\hline & & SRTM1N21E088V3 & $11-02-2000$ & - & & \\
\hline & & SRTM1N21E089V3 & $11-02-2000$ & - & & \\
\hline & & SRTM1N22E087V3 & $11-02-2000$ & - & & \\
\hline & & SRTM1N22E088V3 & $11-02-2000$ & - & & \\
\hline & & SRTM1N22E089V3 & $11-02-2000$ & - & & \\
\hline
\end{tabular}

and, $k=$ (Total Sum of correct-Sum of the all the(row total column total) Total squared-Sum of the all the(row total column total)

The perfect agreement of $\mathrm{K}$ is represented when the kappa value is +1 , while a value of 0 represents no agreement.

\section{Comparison between SAR based flood mapping and MNDWI}

The Modified Normalised Difference Water Index (MNDWI) (Xu 2006) was also used in this flood mapping evaluation to reinforce the results acquired from SAR data processing. This technique has been proven as a useful index-based measurement in a variety of applications including ecological study, LULC change analysis, and accumulated surface water mapping, throughout the world. The formula for calculating MNDWI, is shown in Eq. (5)

$M N D W I=\frac{\text { Green }- \text { SWIR } 1}{\text { Green }+ \text { SWIR } 1}$

The level of surface water accumulation before (Landsat, 04-02-2021 and 22-02-2021) and after the cyclonic storm (Sentinel 2b, 29-05-2021) has been determined based on the band threshold of the area of intertest. In this process, the reader can easily differentiate between flooded and notflooded zone by displaying the archived and crisis index side by side. However, due to the difference in spatial resolution between Landsat and Sentinel $2 b$, a resampling technique was used in the ArcGIS environment to equalize the cell size
Table 2 Characteristics of cyclone Yaas from its generation to depletion over Bay of Bengal during period 23-052021-27-05-2021

\begin{tabular}{llll}
\hline $\begin{array}{l}\text { Date/time (IST) of } \\
\text { the cyclone position }\end{array}$ & Latitude/longitude & $\begin{array}{l}\text { Maximum surface wind } \\
\text { speed (Kmph) }\end{array}$ & Category of cyclonic disturbance \\
\hline $23.05 .21 / 1130$ & $16.1 / 90.2$ & $45-55$ gusting to 65 & Depression \\
$23.05 .21 / 2330$ & $16.6 / 89.8$ & $55-65$ gusting to 75 & Deep depression \\
$24.05 .21 / 0830$ & $16.4 / 89.6$ & $65-75$ gusting to 85 & Cyclonic storm \\
$24.05 .21 / 1130$ & $16.5 / 89.6$ & $70-80$ gusting to 90 & Cyclonic storm \\
$24.05 .21 / 1730$ & $16.8 / 89.5$ & $90-100$ gusting to 110 & Severe cyclonic storm \\
$24.05 .21 / 2330$ & $17.3 / 89.1$ & $110-120$ gusting to 130 & Severe cyclonic storm \\
$25.05 .21 / 0830$ & $18.3 / 88.3$ & $100-110$ gusting to 120 & Severe cyclonic storm \\
$25.05 .21 / 1130$ & $18.7 / 88.0$ & $105-115$ gusting to 125 & Severe cyclonic storm \\
$25.05 .21 / 1730$ & $19.5 / 87.8$ & $125-135$ gusting to 150 & Very severe cyclonic storm \\
$25.05 .21 / 2330$ & $20.1 / 87.6$ & $145-155$ gusting to 170 & Very severe cyclonic storm \\
$26.05 .21 / 0530$ & $20.7 / 87.3$ & $155-165$ gusting to 185 & Very severe cyclonic storm \\
$26.05 .21 / 1130$ & $21.4 / 86.9$ & $120-130$ gusting to 145 & Very severe cyclonic storm \\
$26.05 .21 / 1730$ & $21.8 / 86.6$ & $90-100$ gusting to 110 & Severe cyclonic storm \\
$26.05 .21 / 2330$ & $22.3 / 86.2$ & $60-70$ gusting to 80 & Cyclonic storm \\
$27.05 .21 / 0530$ & $22.9 / 85.6$ & $45-55$ gusting to 65 & Depression \\
\hline
\end{tabular}



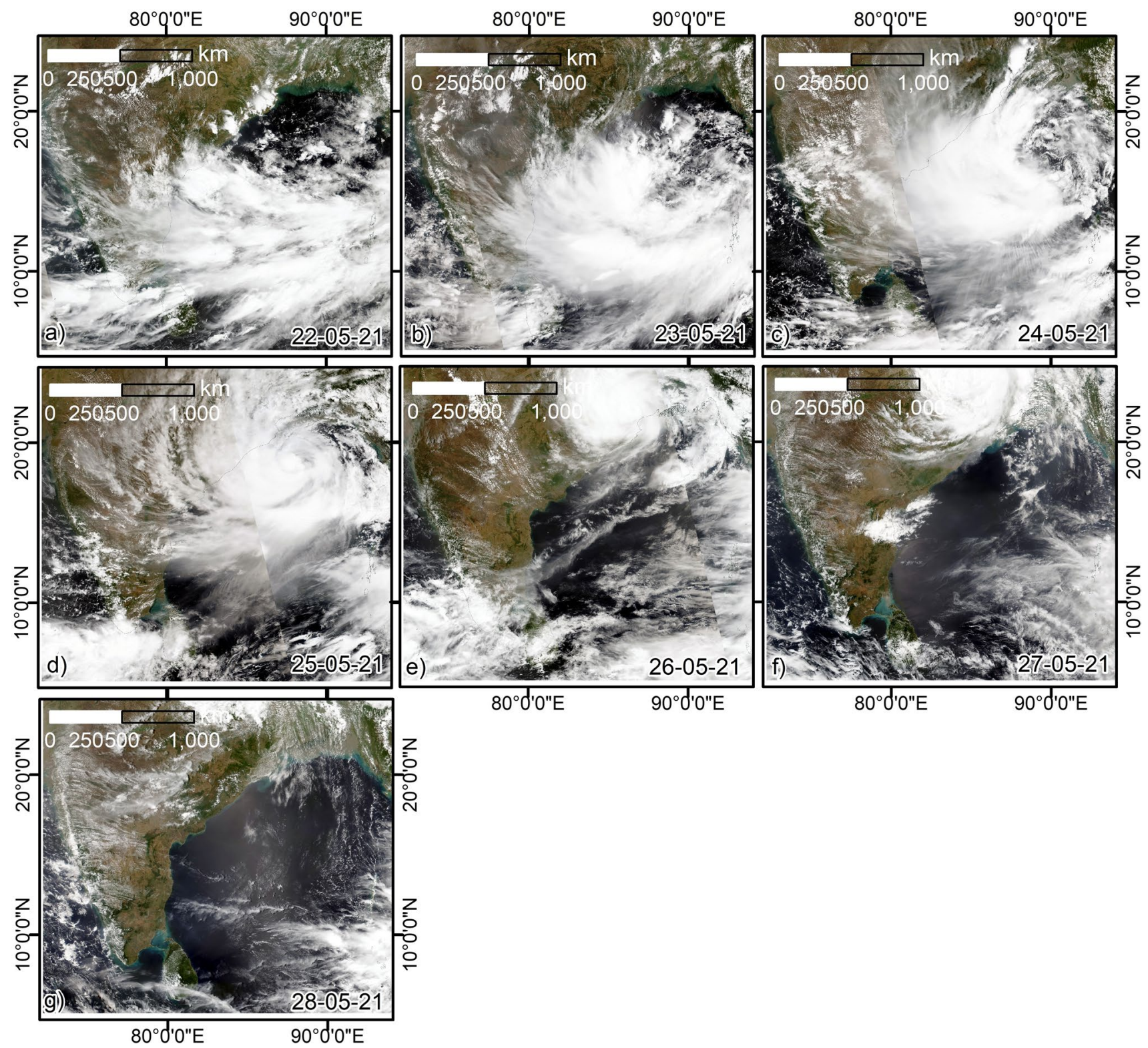

\section{בo}

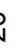

Fig. 2 Space-borne imageries depicting the life cycle of cyclone Yaas from May 22 to May 28, 2021

of both datasets before computing the MNDWI. Also, it is to mention that, we were unable to run the MNDWI for the whole research area, since the satellite images of Landsat series were about 30-70\% cloud-covered after the cyclone period. Only four definable sites from throughout the images were clipped and worked on in that case.

Although, the overall aim of this study is to discuss the characteristics and impact of Cyclone Yaas, readers should have a basic understanding of its management in terms of victim rescue, relief distribution, and rehabilitation during Covid-era, as the study area was at the apex of the covid-19 2nd outbreak during the cyclone's impact period. Accordingly, after analysing the major findings using the methodologies outlined above, an attempt has also been made to provide a preliminary idea of Yaas management in West Bengal.

\section{Results and discussion}

\section{Trajectory and intensity of cyclone Yaas}

Very severe cyclonic storm (VSCS) Yaas was formed over east central Bay of Bengal on 22nd May, 2021 morning (0830 h. IST) as a depression (D) and gradually intensified to deep depression (DD) and further intensified as it turned 

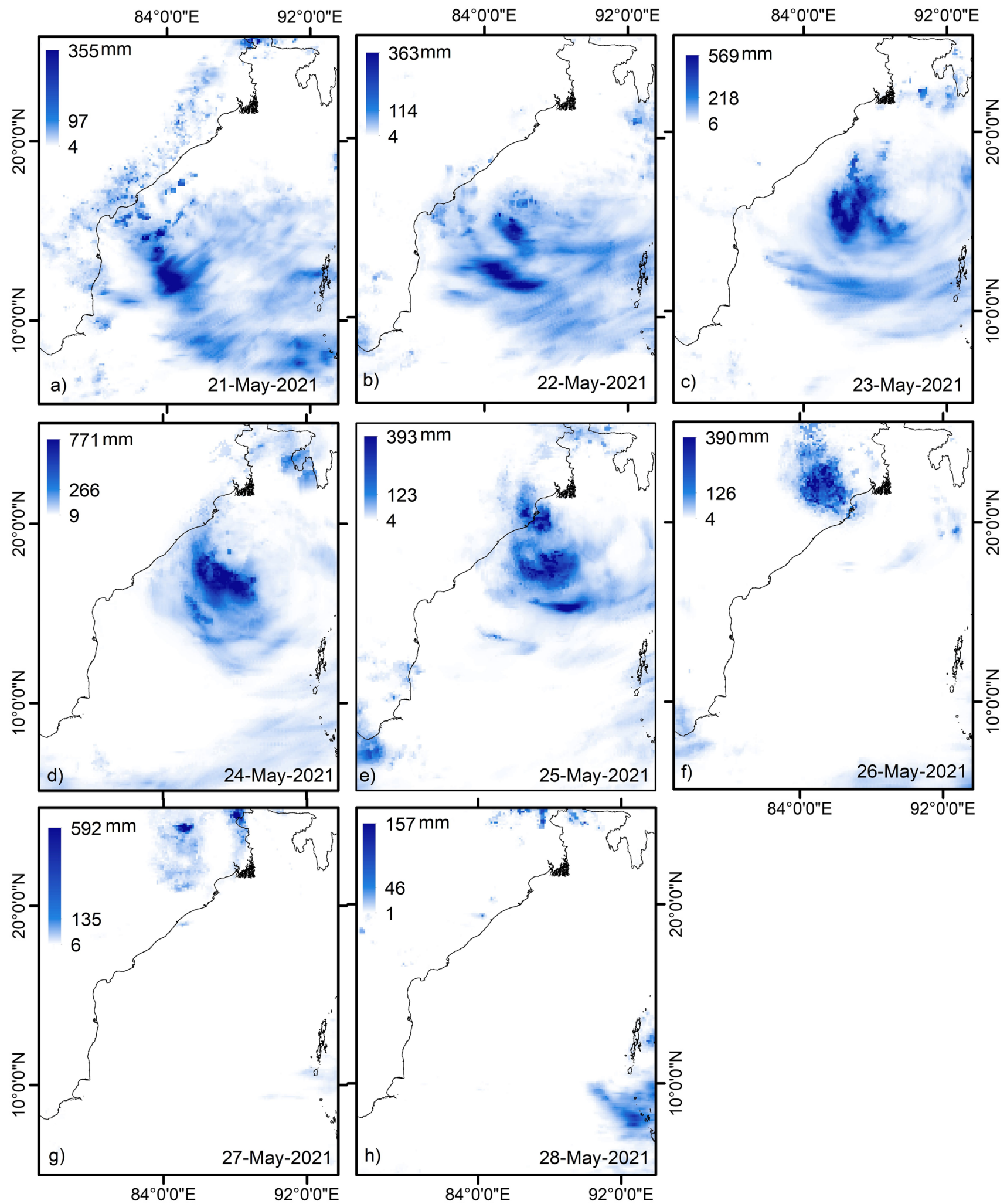

Fig. 3 Spatio-temporal variability of cyclonic rainfall during period May 21-May 28, 2021 
Table 3 Assessment result of flood affected area and flood affected population in the study area

\begin{tabular}{|c|c|c|c|c|c|c|}
\hline District name & Block name & Total area $\left(\mathrm{km}^{2}\right)$ & $\begin{array}{l}\text { Flooded area due to either embank- } \\
\text { ment breeching or overtopping }\left(\mathrm{km}^{2}\right)\end{array}$ & $\begin{array}{l}\text { Total popula- } \\
\text { tion }(2011)\end{array}$ & $\begin{array}{l}\text { Flood effected } \\
\text { population }\end{array}$ & $\begin{array}{l}\text { No of } \\
\text { affected } \\
\text { village }\end{array}$ \\
\hline \multirow[t]{8}{*}{ South 24 Parganas } & Sagar & 282.11 & 37.10 & 212,037 & 60,106 & 13 \\
\hline & Namkhana & 370.61 & 78.12 & 182,830 & 79,823 & 15 \\
\hline & Kakdwip & 252.70 & 32.59 & 281,963 & 54,256 & 14 \\
\hline & Kulpi & 210.80 & 23.80 & 283,197 & 4875 & 4 \\
\hline & Mathurapur & 227.40 & 9.88 & 220,839 & 6500 & 2 \\
\hline & Pathar Pratima & 484.50 & 58.74 & 331,823 & 34,921 & 13 \\
\hline & Kultali & 306.20 & 13.66 & 229,053 & 7800 & 3 \\
\hline & Gosaba & 296.70 & 27.35 & 246,598 & 32,885 & 8 \\
\hline \multirow[t]{3}{*}{ North 24 Parganas } & Sandeshkhali I & 182.30 & 2.08 & 164,465 & 4200 & 2 \\
\hline & Sandeshkhali II & 197.20 & 4.08 & 160,976 & 1500 & 2 \\
\hline & Hingalganj & 238.80 & 4.68 & 159,469 & 8700 & 1 \\
\hline \multirow[t]{8}{*}{ Purba Midnapur } & Ramnagar I & 139.43 & 15.24 & 167,330 & 14,195 & 18 \\
\hline & Ramnagar II & 163.30 & 19.62 & 156,054 & 7500 & 6 \\
\hline & Contai I & 139.40 & 4.57 & 170,894 & 6500 & 12 \\
\hline & Deshopran & 170.30 & 19.54 & 176,393 & 5950 & 7 \\
\hline & Khejuri II & 137.50 & 22.27 & 139,463 & 7800 & 10 \\
\hline & Nandigram I & 181.80 & 26.27 & 207,835 & 5877 & 8 \\
\hline & Haldia & 65.44 & 6.62 & 97,992 & 4050 & 5 \\
\hline & Sutahata & & 24.58 & 123,784 & 1000 & 2 \\
\hline
\end{tabular}

northeast, becoming a cyclonic storm (CS) on 24th May, 2021 at 00:00 IST with a central pressure of $990 \mathrm{hpa}$ and a wind speed of $35 \mathrm{KT}$ at $16.4^{\circ} \mathrm{N}$ and $89.6^{\circ} \mathrm{E}$ (Fig. 1b). Therefore, it had strengthened into severe cyclonic storm (SCS) by 24th may, 2021 at 18:00 IST that lasted for $12 \mathrm{~h}$ and had winds of 48-63 KT, until it reached very severe cyclonic storm. Accordingly, around 12:00 IST on May 25, 2021, the cyclone transitioned into VSCS at $19.5^{\circ} \mathrm{N}$ and $87.8^{\circ} \mathrm{E}$, taking a strong north-eastern route and moving steadily landward with a wind speed of 64-89 KT. Finally, made its landfall at about $20 \mathrm{~km}$ to the south of Balasore over north Odisha coast at $21.35^{\circ} \mathrm{N}$ and $86.95^{\circ} \mathrm{E}$, with a maximum sustained wind speed of 130-140 kmph gusting to $155 \mathrm{kmph}$ between 10:30 \& 11:30 h IST, of 26th May, 2021 before weakening to a depression over central Jharkhand around 11:30 IST on the 27th of May, 2021 (Table 2). Therefore, it is clear that about $700 \mathrm{~km}$ out of the $1005 \mathrm{~km}$ trajectory of cyclone Yaas passed through the Bay of Bengal until it was depleted (Fig. 2), accumulated energy, and devastatingly impacted the coastal regions. Following the trajectory, the major damage was expected to be in the north coastal districts of Odisha and the adjoining districts of West Bengal such as East Medinipur, but strong winds induced storm surges above the astronomical tidal level inundated the vast low lying of South 24 Parganas and North 24 Parganas districts, as discussed in Sect. 4.3.

\section{Precipitation variability of cyclone Yaas}

The GPM-based data shows that from the 21st of May, 2021 to the cyclone depletion, the maximum daily rainfall (about $771 \mathrm{~mm}$ ) was received by coastal areas such as Ratanpur, Bhadrak, and Balasore in Odisha and East Medinipur in West Bengal on May, 24, 2021. The minimal rainfall, on the other hand, occurred on May 28th, a day after the storm made landfall, with an amount of $157 \mathrm{~mm}$. Side by side, a moderate intensified rainfall was received since the onset of the cyclone depression until it turned into a VSCS. As such the date like 21st, 22nd, and 23rd received $355 \mathrm{~mm}$, $363 \mathrm{~mm}$, and $569 \mathrm{~mm}$ rainfall, respectively. However, despite turned into a VSCS, the level of rainfall on the day of landfall and the day prior was also moderate type $(390 \mathrm{~mm}$ and $393 \mathrm{~mm}$ respectively). Therefore, the result demonstrates that between 21st May and 28th May, the cyclone affected regions in the Indian Subcontinent including the Bay of Bengal, received about 1196 mm of rainfall. However, during the same period, the terrestrial areas got about $536 \mathrm{~mm}$ of cyclonic rainfall (Fig. 3).

An hourly data analysis of the day of cyclonic landfall from the GPM reveals that rainfall was at its peak $(131.8 \mathrm{~mm}$ cumulatively) from 2 A.M. to 5 A.M., where the landfall process was occurred at 6 A.M. Although, the average rainfall over the next $10 \mathrm{~h}$ was reduced to $37.12 \mathrm{~mm} / \mathrm{h}$. However, after 3 p.m., the rainfall continued to increase until around 


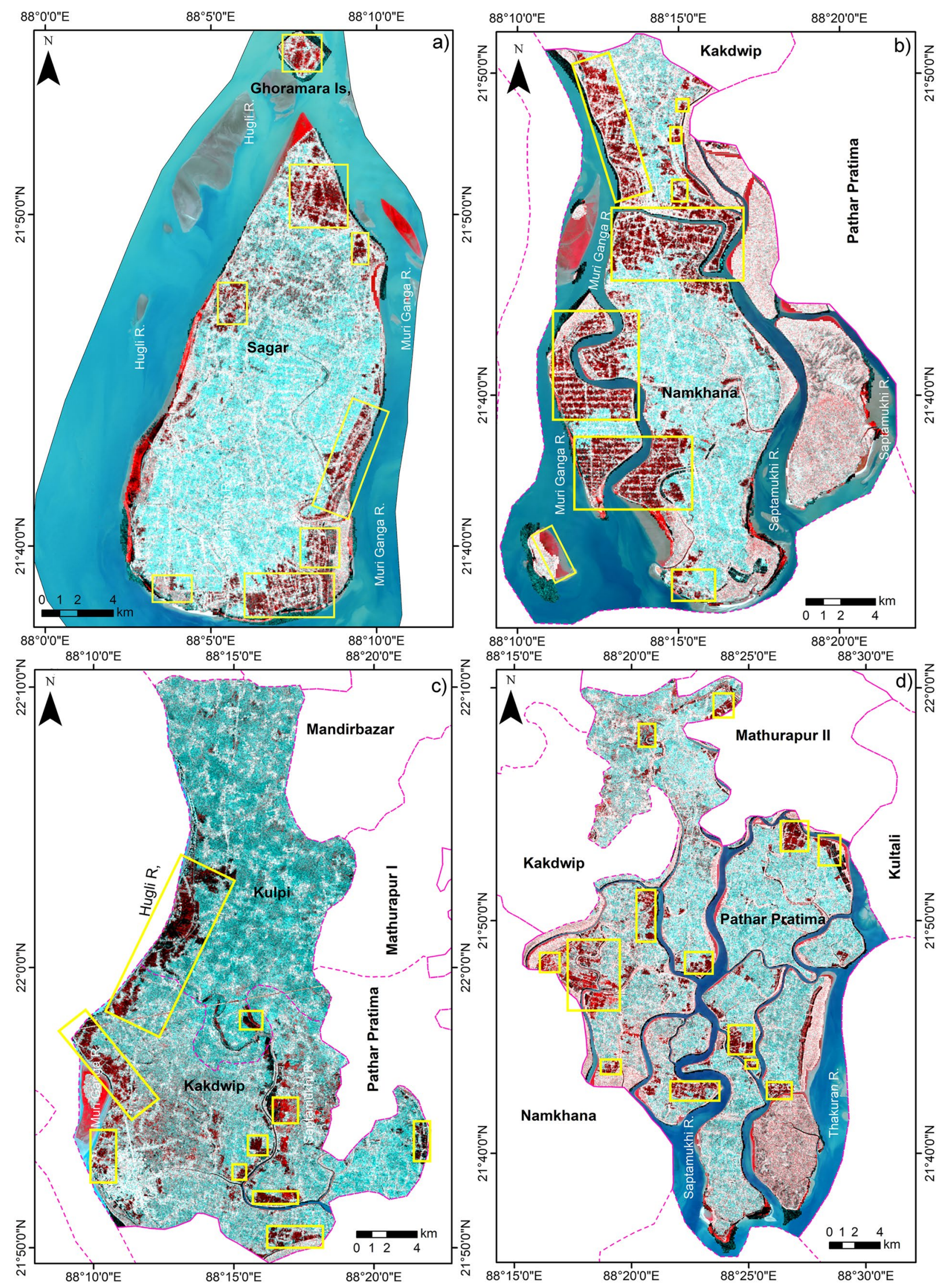

Fig. 4 Storm surge induced coastal flooding a Sagar, b Namkhana, c Kulpi, and d Pathar Pratima 

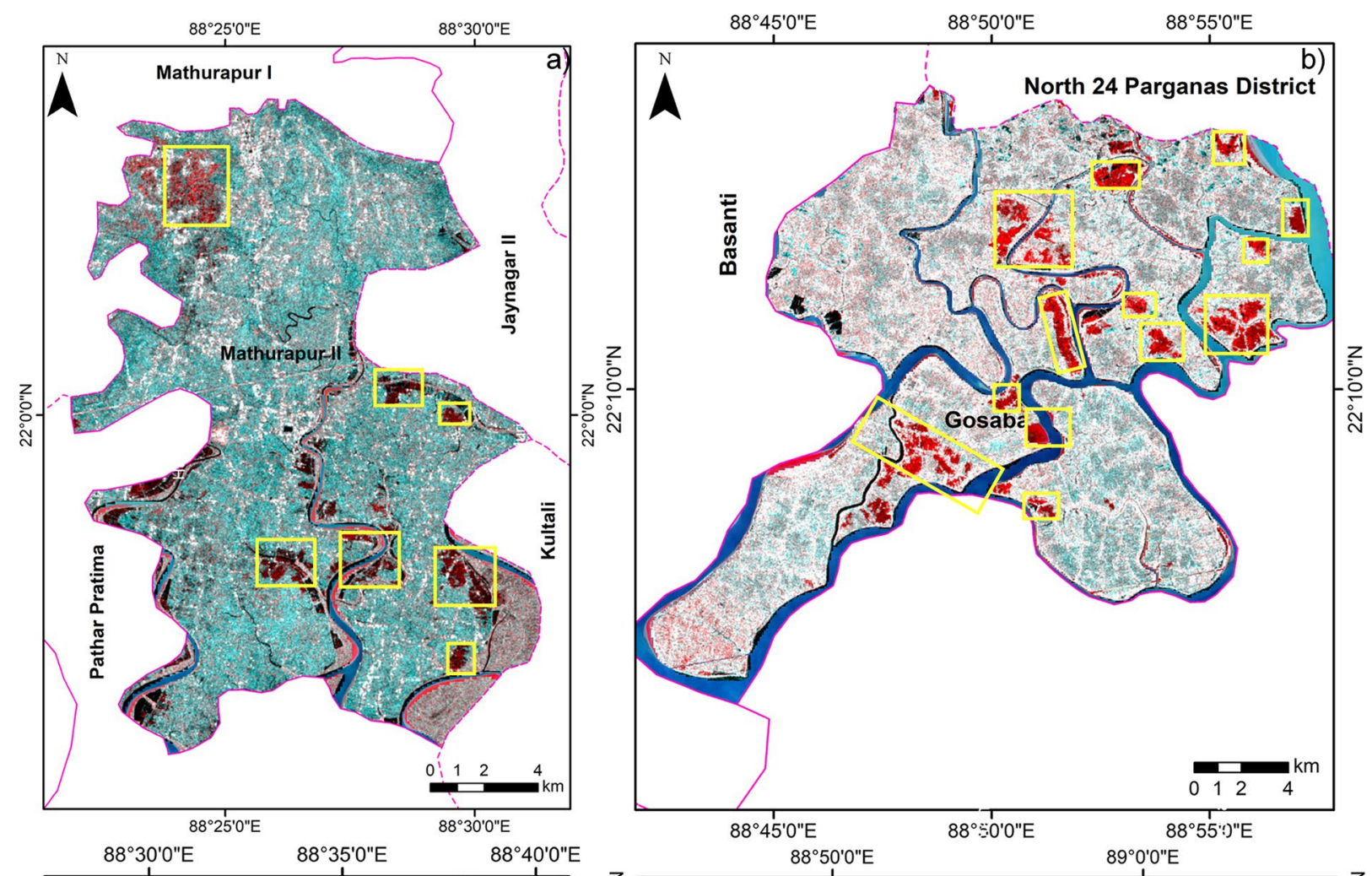

\section{$z$}

2.

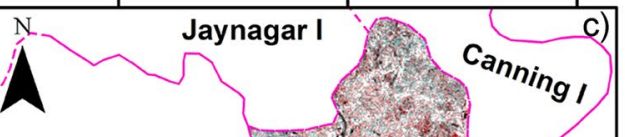

กิ-

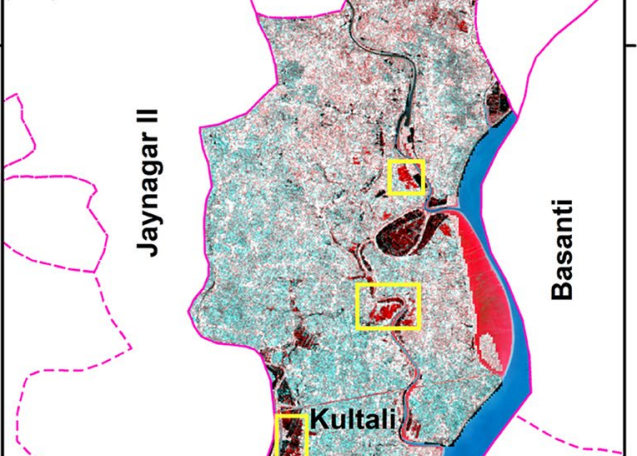

วั้

ลें
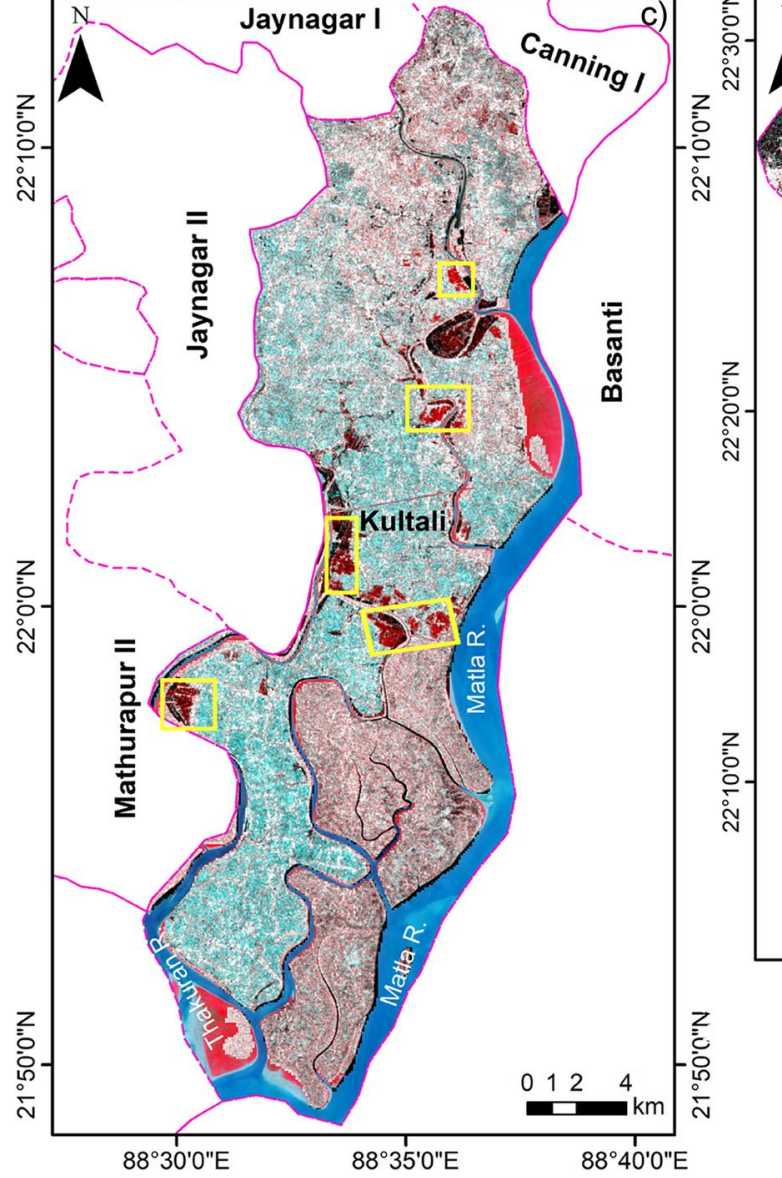

$88^{\circ} 50^{\prime} 0 " \mathrm{E}$

8900

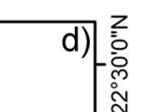

z

ลे
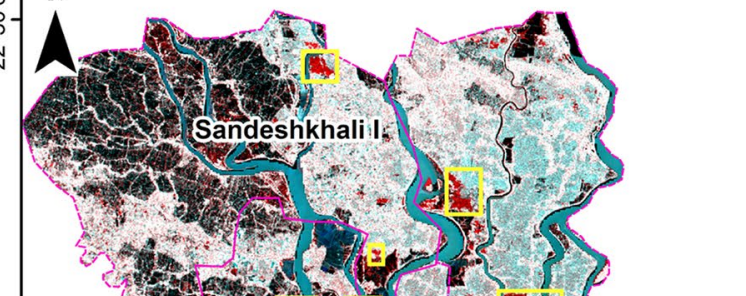

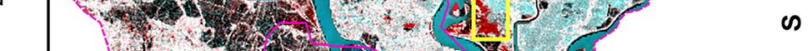

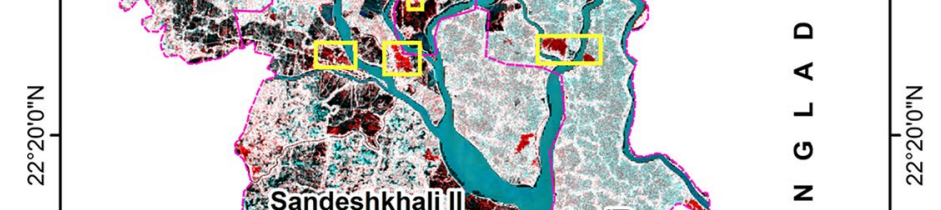

$0124 \mathrm{~km}$

$88^{\circ} 50^{\prime} 0 " \mathrm{E}$

$89^{\circ} 0^{\prime} \mathrm{O}^{\prime \prime} \mathrm{E}$

Fig. 5 Storm surge induced coastal flooding a Mathurapur I, b Gosaba, c Kultali, and d selected blocks of North 24 parganas 

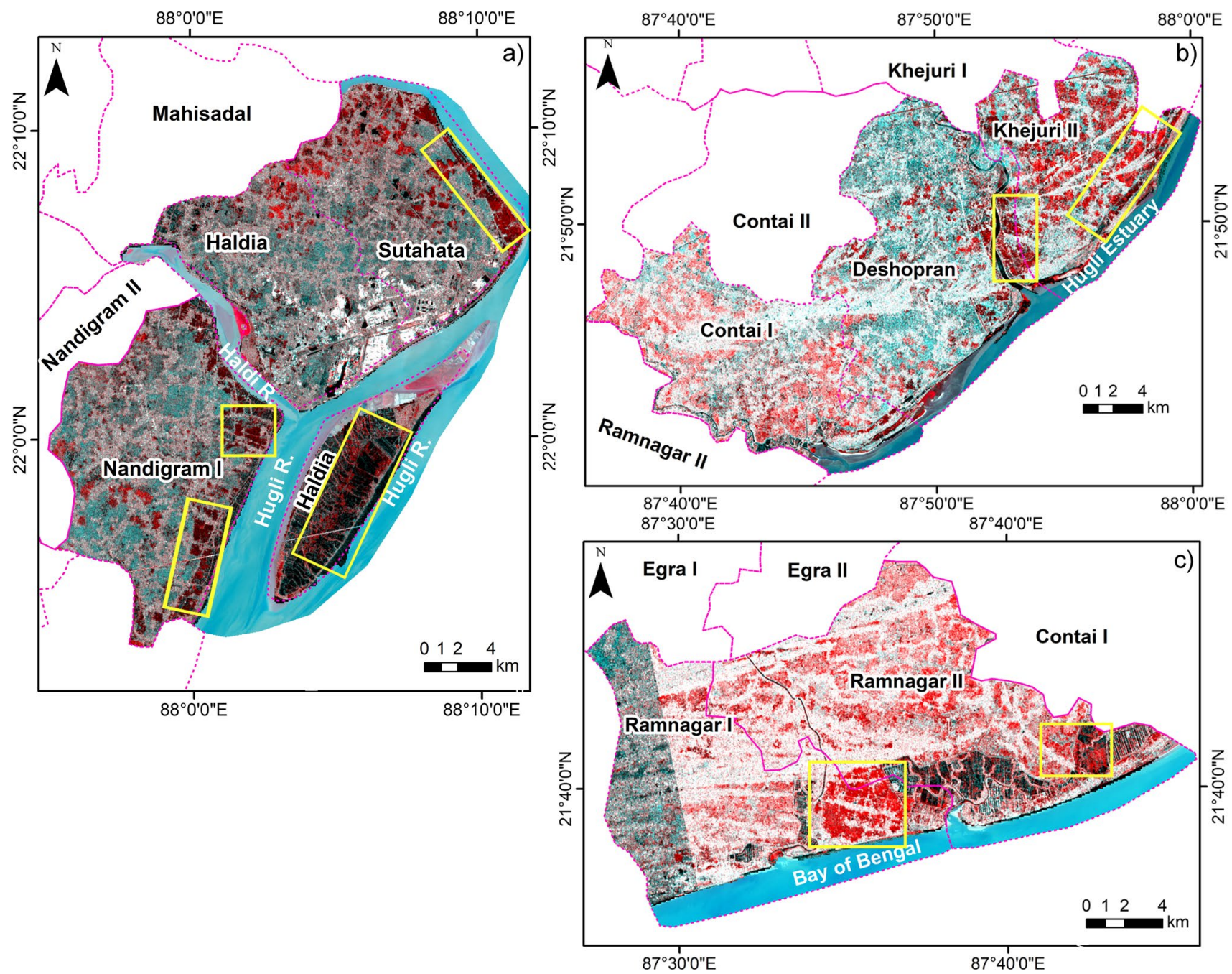

Fig. 6 Storm surge induced coastal flooding a Nandigram, Haldia, and Sutahata, b Contai I, Deshopran, and Khejuri II, c Ramnagar I and Ramnagar II

6 in the evening, when it began to diminish again. In the whole process, the East Medinipur district in West Bengal received the most rainfall, followed by the South and North 24 Parganas. Accordingly, a spatial distribution shows that East Medinipur received a total of $129 \mathrm{~mm}$ rainfall between period 21st-28th May, while South and North 24 Parganas received $85 \mathrm{~mm}$ and $81 \mathrm{~mm}$ in the same period, respectively.

\section{Storm surge and resultant inundation}

Within 2 to $3 \mathrm{~h}$ of the landfall on May 26, massive inundation was observed in the East Medinipur coastal tract, the low-lying coastal blocks of South 24 Parganas, and some specific locations in the North 24 Parganas district bordering the Sundarbans, as shown in Table 3. As such, about $281.2 \mathrm{~km}^{2}$ of land (11.6\% of district area) in South 24 Parganas was flooded, followed by East Medinipur $\left(138.7 \mathrm{~km}^{2}, 12.4 \%\right.$ of district area) and North 24 Parganas $\left(10.8 \mathrm{~km}^{2}, 1.7 \%\right.$ of district area). Accordingly, the most affected coastal blocks in South 24 parganas in terms of flooded area were Namkhana $\left(78.1 \mathrm{~km}^{2}\right)$, Patharpratima $\left(58.7 \mathrm{~km}^{2}\right)$, Sagar $\left(37.1 \mathrm{~km}^{2}\right)$, Kakdwip (32.6 km²) respectively (Fig. 4), followed by other interior blocks like Gosaba $\left(27.3 \mathrm{~km}^{2}\right)$, Kulpi $\left(23.8 \mathrm{~km}^{2}\right)$, Kultali $\left(13.7 \mathrm{~km}^{2}\right)$, and Mathurapur $\left(9.8 \mathrm{~km}^{2}\right)$ (Fig. 5). The flood affected populations are also high in Namkhana (43.6\% of block population), Sagar (28.3\%), Kakdwip (19.2\%), Gosaba (13.3\%), Patharpratima (10.5\%), Kultali (3.4\%), Mathurapur (2.9\%), and Kulpi (1.7\%) block. Similarly, the East Medinipur coastal tract has been severely damaged due to its proximity to the Odisha coast, with the majority of devastation found in Nandigram I $\left(26.3 \mathrm{~km}^{2}\right)$ Sutahata $\left(24.6 \mathrm{~km}^{2}\right)$, Khejuri II $\left(22.3 \mathrm{~km}^{2}\right)$ and Ramnagar II (19.7 km²) (Fig. 6), followed by Deshopran, Ramnagar I, Haldia, and Contai block (Fig. 7). Most of the damage to these coastal regions was triggered 

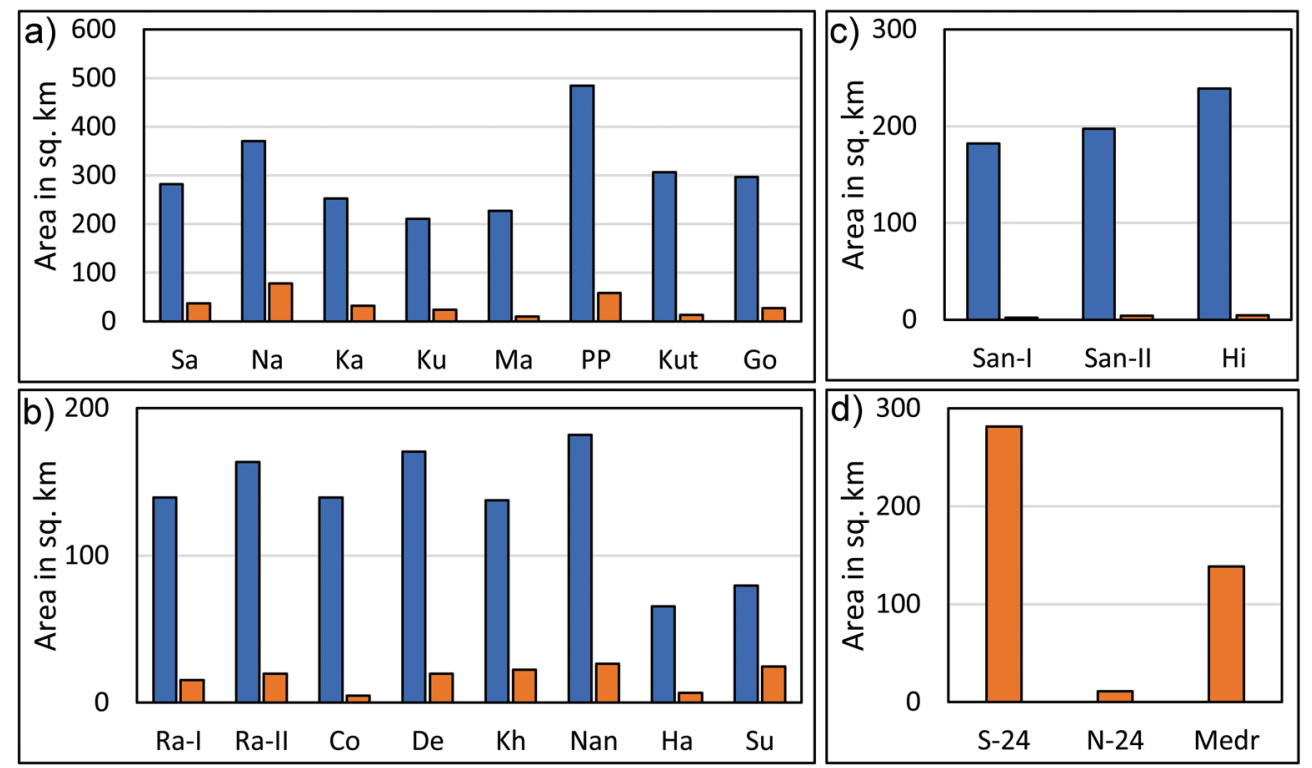

Sa-Sagar
Na-Namkhana
Ka- Kakdwip
Ku-Kulpi
Ma- Mathurapur
PP- Pathar Pratima
Kut- Kultali
Go- Gosaba
San-I- Sandeshkhali I
San-II- Sandeshkhali II
Hi- Hingalganj
Ra-I- Ramnagar I
Ra-II- Ramnagar II
Co- Contai I
De- Deshopran
Kh- Khejuri III
Nan- Nandigram I
Ha- Haldia I
Su- Sutahata
S-24- South 24 Parganas
N-24- North 24 Parganas
Medr- East Medinipur

Medr- East Medinipur

Fig. 7 Graphical representation of inundation areas, a level of inundation in selected blocks of South 24 Parganas, b in selected blocks of North 24 Parganas, $\mathbf{c}$ in selected blocks of East Medinipur, and $\mathbf{d}$ comparison of inundation areas between coastal districts of West Bengal

either due to the breaching of river embankment as seen in different parts of South and North 24 parganas, or by overtopping of high stormy waves over the concreate sea wall, as seen in the coastal areas of Medinipur district. Moreover, it should be noted that maximum waterlogging has been found around the Hugli estuary region, including all islands such as Sagar, Ghoramara, Mousuni, G-plot, and Kakdwip, due to the reported storm surge height of 2-3 m above the normal tidal water level, as landfall coincided with the full moon high tide condition on May 26, 2021 (Fig. 8). In other words, it has been observed that whenever a storm strikes coastal West Bengal at a time when the tidal level is high, the damage was considerable, and vice versa. In this perspective, cyclone Amphan in 2020 (during low tidal face), which had a maximum wind speed of $220 \mathrm{~km} / \mathrm{h}$, did not create as much flooding in West Bengal as cyclone Yaas, which had a maximum wind speed of $70-80 \mathrm{~km} / \mathrm{h}$, as recorded in Digha, West Bengal (Das et al. 2020). Observing the results, therefore, it is indeed reasonable to assume that if the cyclone had shifted its path to the West Bengal coast instead of Odisha, the dam-age would have been worse than that of cyclone Aila in 2009.

\section{Accuracy assessment of the extracted flood area}

In this study Kappa co-efficient as well as derivation of MNDWI both has been applied to find out the accuracy. As such, ground truth-based accuracy assessment for the inundation map shows that the overall accuracy is equivalent to about $98 \%$, while the kappa coefficient of the classified result is about 0.97 , signifies its high accuracy. The inundation outcome has also been carefully examined by analyzing the variations in MNDWI values during the pre-cyclone and post-cyclone periods in selected portions of the study area viz. Sagar, Namkhana, Patharpratima, and Mandarmoni. The comparison of MNDWI and SAR-based inundation mapping reveals that site with positive MNDWI values are likewise identified in the SAR-based inundation map, indicating that the SAR-based inundation map offers appropriate accuracy.

\section{Impact of Covid-19 2nd wave on the management of the Yaas}

It has been mentioned earlier that the impact of this devastating cyclonic wind is less is West Bengal, but the effect of strong storm surge made from it, has had a huge impact on the local inhabitants of coastal districts of West Bengal. Around $1200 \mathrm{~km}^{2}$ area have been suffered by this cyclone, and millions of people have faced the deadliest effect, including salt water intrusion in the surface water-bodies, the breaking of mud-built houses in low-income areas of East Medinipur and South 24 Parganas, submergence of paddy field, the breaking down of electric supply and so on. On the other hand, while all this damage was going on, India and West Bengal were already dealing with the second wave of 

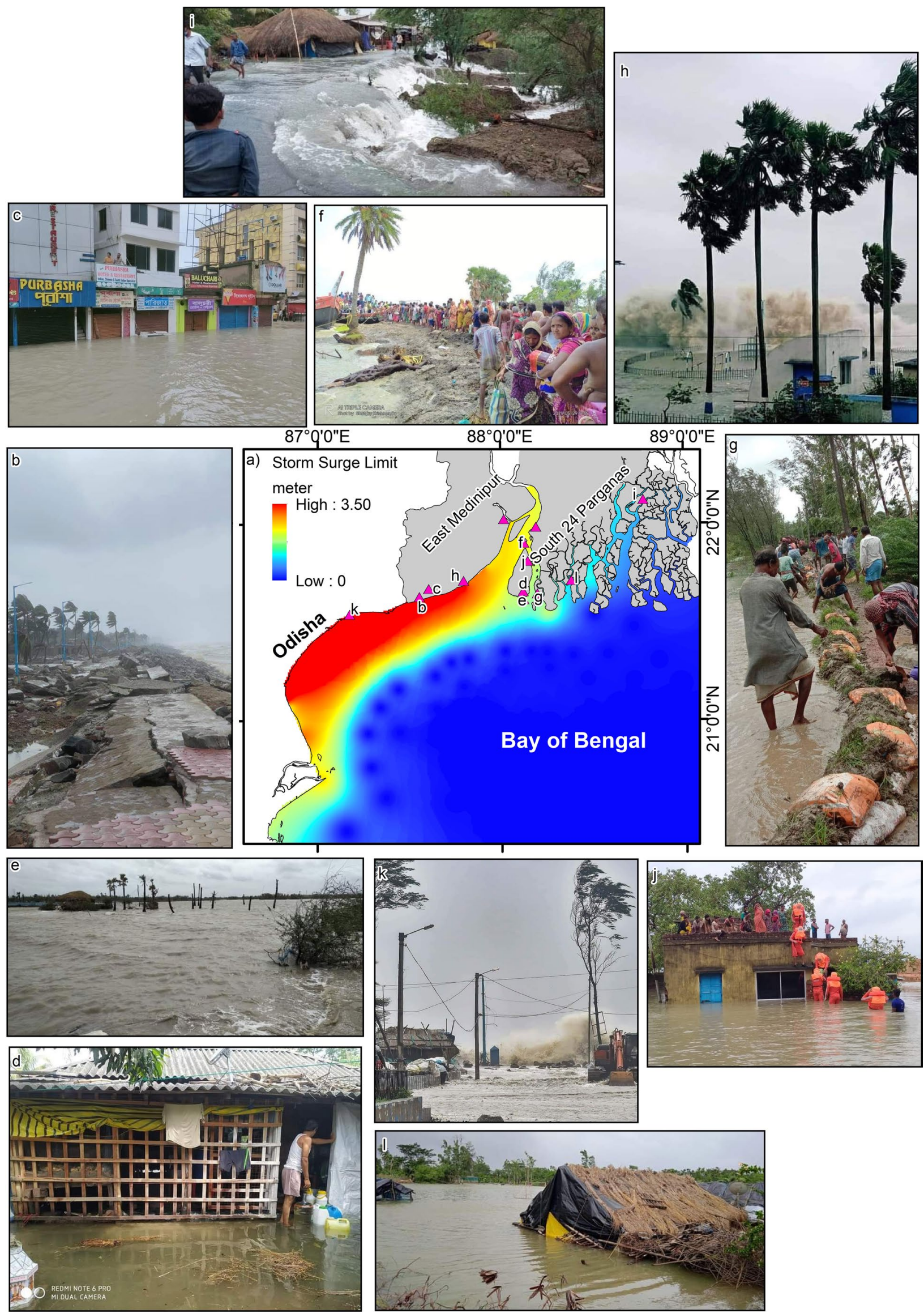

$88^{\circ} Q^{\prime} 0 " E$

$89^{\circ} \mathrm{g}^{\prime} \mathrm{O}=\mathrm{E}$
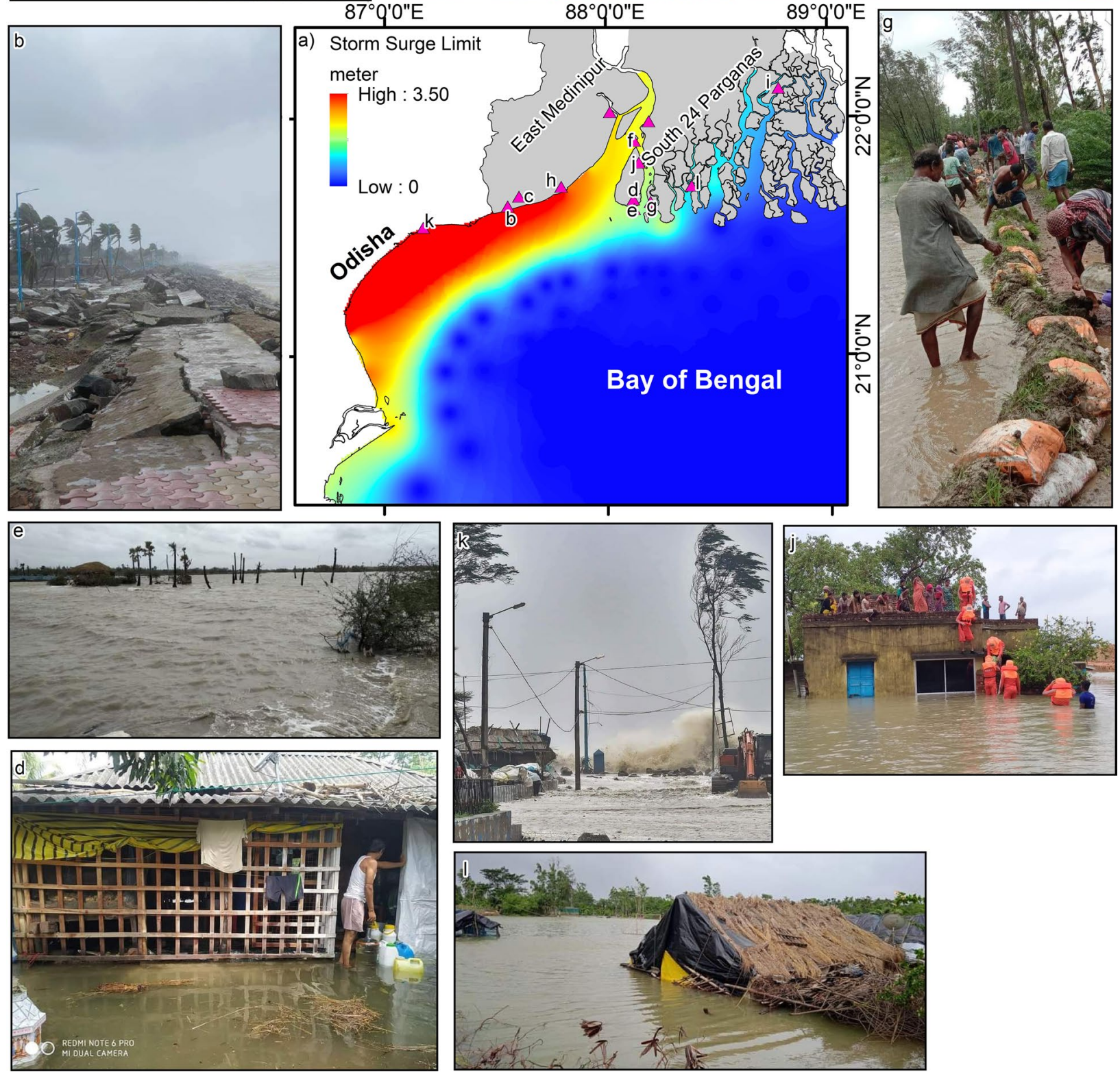
4Fig. 8 Reported Storm surge and photographic documentation of cyclone Yaas; a spatio temporal variability of storm surge, b collapse of concrete sea wall at Digha, $\mathbf{c}, \mathbf{d}$, and $\mathbf{e}$ inundation in Digha marketplace, Sagar, and Botkhali respectively, $\mathbf{f}$ rescue of local residents from Ghoramara island, $\mathbf{g}$ reconstruction of damaged embankments by the local people, $\mathbf{h}$ storm surge at Mandarmoni, East Medinipur, $\mathbf{i}$ havoc inundation in Sagar island, $\mathbf{j}$ rescue operation in Ghoramara island during the cyclone, $\mathbf{k}$ storm surge at Puri, Odisha; Source a INCOIS (daily ocean report, 26/05/2021), f NDMF (Bulletin, $30 / 05 / 2021)$

the pandemic Covid-19 disease. In this regard, if we simply examine the day of cyclonic landfall, the total reported active covid-19 cases in East Medinipur was around 5347, in South 24 Parganas 8136, and in North 24 Parganas the total number of covid cases exceeded 25,365 persons. In this scenario, when West Bengal declares a public health emergency in terms of lock down to protect people from infection, many people have been displaced from different vulnerable coastal areas, and forced to live in government multipurpose cyclone centers, schools, or community halls due to submergence in the respective areas and resulted breaking down of residential areas. Therefore, sheltering the affected people from cyclone induced flooding and at the same time protecting them from Covid-19 was a big challenge for the local government and policy builders, when the means of transportation are closed and there is a shortage of medicine throughout the country. Needless to say, the disaster management department has been able to fight against both the crises through the joint effort of National Disaster Response Force (NDRF), local police, government aided clubs, and conscious people.

\section{Conclusion}

The study has demonstrated the characteristics of the cyclone Yaas in terms of its formation, propagation, wind strength, landfall, and rainfall intensity as well as related flood inundation in the lower part of West Bengal. In that case, remote sensing technology gives a prospect for quick and immediate investigation of the extent of any meteorological event, including tropical cyclone induced inundation on affected areas. The space-borne data reveals that the amount of cumulative rainfall throughout this 7-day occurrence reaches $1196 \mathrm{~mm}$ over the Indian subcontinent, with the highest daily rainfall (around $771 \mathrm{~mm}$ ) received by coastal places including Ratanpur, Bhadrak, and Balasore in Odisha and East Medinipur in West Bengal on May 24, 2021. Beside this stormy winds and rainfall, high storm induced surges coupling with full moon situation has caused havoc devastation in the coastal areas of Odisha and West Bengal. The availability of real time Sentinel-1 SAR imagery has also confirmed the massive inundation in the coastal areas of West Bengal. Numerous coastal embankments and riverine flood shields have collapsed, leading in the submergence of agricultural areas, power outages, and the collapse of mud dwellings, and so on. Inundation mapping, therefore, shows that the reclaimed areas of Sundarbans and the islands around the Hugli estuary have been most damaged by this storm, but the substantial impact of landfall has been observed in East Medinipur districts owing to the coast next to Odisha. The study, therefore, gave an accurate evaluation of the catastrophic effects of Cyclone Yaas, which can aid in the development of efficient disaster risk reduction preparedness methods.

Acknowledgements The authors would like to thank some of the residents of Sagar, Namkhana, and Digha who helped us during postcyclonic assessments of impacted regions. The authors are also thankful to European Space Agency (ESA), the United States Geological Survey (USGS), and the Indian Meteorological Department (IMD) for providing us relevant satellite images, meteorological data, and other related information.

Funding None.

\section{Declarations}

Conflict of interest We declare that we have no known competing financial interests or personal relationships that could have appeared to influence the work reported in this paper.

\section{References}

Ahammed KKB, Pandey AC (2021) Characterization and impact assessment of super cyclonic storm AMPHAN in the Indian subcontinent through space borne observations. Ocean Coast Manag 205:105532. https://doi.org/10.1016/j.ocecoaman.2021.105532

Ali SA, Khatun R, Ahmad A, Ahmad SN (2019) Assessment of cyclone vulnerability, hazard evaluation and mitigation capacity for analyzing cyclone risk using gis technique: a study on sundarban biosphere reserve, India. Earth Syst Environ 4:71-92. https:// doi.org/10.1007/s41748-019-00140-x

Barzycka B, Grabiec M, Jania J (2019) Remote sensing of environment glacier facies of vestfonna ( Svalbard) based on SAR images and GPR measurements. Remote Sens Environ 221:373-385. https:// doi.org/10.1016/j.rse.2018.11.020

Bhardwaj P, Singh O (2021) Active and inactive tropical cyclone years over the Bay of Bengal: 1972-2015. J Earth Syst Sci 130:1-15. https://doi.org/10.1007/s12040-021-01597-z

Bhardwaj P, Singh O, Pattanaik DR, Klotzbach PJ (2019) Modulation of bay of bengal tropical cyclone activity by the madden-julian oscillation. Atmos Res 229:23-38. https://doi.org/10.1016/j.atmos res.2019.06.010

Bhaskaran PK, Rao AD, Murty T (2020) Tropical cyclone-induced storm surges and wind waves in the Bay of Bengal. In: Singh SK, Mohanty UC, Murty T (eds) Techniques for disaster risk management and mitigation, 1st edn. pp 239-265

Bielli S, Barthe C, Bousquer O, Tulet P (2021) The effect of atmosphere: the effect of atmosphere-ocean coupling on the structure and intensity of tropical cyclone Bejisa in the Southwest Indian 
Ocean. Atmosphere (basel) 12:1-17. https://doi.org/10.3390/ atmos 12060688

BMTPC (2006) vulnerability atlas of india natural hazard maps and damage risk to housing

Brammer H (2014) Bangladesh's dynamic coastal regions and sealevel rise. Clim Risk Manag 1:51-62. https://doi.org/10.1016/j. crm.2013.10.001

Castillo JAA, Apan AA, Maraseni TN, Salmo SG (2017) Estimation and mapping of above-ground biomass of mangrove forests and their replacement land uses in the Philippines using Sentinel imagery. ISPRS J Photogramm Remote Sens 134:70-85. https:// doi.org/10.1016/j.isprsjprs.2017.10.016

Das S, Das A, Kar NS, Bandyopadhyay S (2020) Cyclone Amphan and its impact on the Lower Deltaic West Bengal : a preliminary assessment using remote sensing sources Cyclone Amphan and its impact on the Lower Deltaic West Bengal : a preliminary assessment using remote sensing sources. Curr Sci 119:12451250. https://doi.org/10.18520/cs/v119/i8/1246-1249

DasGupta R, Shaw R (2015) An indicator based approach to assess coastal communities' resilience against climate related disasters in Indian Sundarbans. J Child Fam Stud 24:85-101. https://doi. org/10.1007/s11852-014-0369-1

Dasgupta S, Huq M, Khan Z, et al (2010) Vulnerability of Bangladesh to Cyclones in a Changing Climate: Potential Damages and Adaptation Cost. World Bank Policy Res Work Pap

Deb SK, Kumar P, Pal PK, Joshi PC (2011) International Journal of Remote Assimilation of INSAT data in the simulation of the recent tropical Cyclone Aila. Int J Remote Sens 32:5135-5155. https://doi.org/10.1080/01431161.2010.494640

Debnath A (2013) Physicochemical quality of ethiopian plantation white sugar from three sugar factories. Int J Sci Res Publ 5:128-133

Engelbrecht J, Theron A, Vhengani L, Kemp J (2017) A simple normalized difference approach to burnt area mapping using multipolarisation C-band SAR. Remote Sens 9:9-11. https://doi.org/ 10.3390/rs9080764

Gayathri R, Bhaskaran PK, Sen D (2015) Numerical study on storm surge and associated coastal inundation for 2009 AILA cyclone in the head Bay of Bengal. Aquat Procedia 4:404-411. https:// doi.org/10.1016/j.aqpro.2015.02.054

Gayathri R, Murty PLN, Bhaskaran PK, Srinivasa Kumar T (2016) A numerical study of hypothetical storm surge and coastal inundation for AILA cyclone in the Bay of Bengal. Environ Fluid Mech 16:429-452. https://doi.org/10.1007/s10652-015-9434-z

Ghosh M, Ghosal S (2021) Climate change vulnerability of rural households in flood-prone areas of Himalayan foothills, West Bengal, India. Environ Dev Sustain 23:2570-2595. https://doi. org/10.1007/s10668-020-00687-0

Halder B, Das S, Bandyopadhyay J, Banik P (2021) The deadliest tropical cyclone 'Amphan': investigate the natural flood inundation over south 24 Parganas using google earth engine. Saf Extrem Environ 23:1-11. https://doi.org/10.1007/ s42797-021-00035-z

Hossain MS, Karlson M, Neset TS (2019) Application of gis for cyclone vulnerability analysis of Bangladesh. Earth Sci Malays 3:25-34. https://doi.org/10.26480/esmy.01.2019.25.34

IIT (2006) Hazard assessment and disaster mitigation for west bengal due to tropical cyclones. http://www.iczmpwb.org/main/pdf/ ebooks. Accessed 30 May 2021

IMD (2021a) Deep Depression (Remnant of ,YAAS ${ }^{\text {e* }}$, weakened into a Depression over central parts of Jharkhand. https://mausam.imd. gov.in/Forecast/marquee_data. Accessed 28 May 2021

IMD (2021b) cyclone warning in india standard operation procedure. https://mausam.imd.gov.in/Forecast/marquee_data/1_ceda68_14. National_Bulletin. Accessed 28 May 2021
Kellndorfer JM, Pierce LE, Dobson MC et al (1998) Toward consistent regional-to-global-scale vegetation characterization using orbital SAR systems. Trans Geosci Remote Sens 36:1396-1411. https:// doi.org/10.1109/36.718844

Klemas V (2015) Remote sensing of floods and flood-prone areas : an overview. J Coast Res 31:1005-1013. https://doi.org/10.2112/ JCOASTRES-D-14-00160.1

Klemas VV (2009) The role of remote sensing in predicting and determining coastal storm impacts the role of remote sensing in predicting and determining coastal storm impacts. J Coast Res. https://doi.org/10.2112/08-1146.1

Kumar R (2017) Flood inundation and hazard mapping of 2017 floods in the rapti river basin using sentinel-1a synthetic aperture radar images. In: Applications and Challenges ofGeospatial Technology. pp 77-89

Kunze S (2021) Unraveling the effects of tropical cyclones on economic sectors worldwide: direct and indirect impacts. Environ Resour Econ 78:545-569. https://doi.org/10.1007/s10640-021-00541-5

Li B, Zhou L, Wang C et al (2020) Modulation of tropical Cyclone genesis in the Bay of Bengal by the central modulation of tropical cyclone genesis in the Bay of Bengal by the Central Indian Ocean Mode. JGR Atmos 125:12. https://doi.org/10.1029/2020JD032641

Liu C, Frazier P, Kumar L (2007) Comparative assessment of the measures of thematic classification accuracy. Remote Sens Environ 107:606-616. https://doi.org/10.1016/j.rse.2006.10.010

Mansaray LR, Huang W, Zhang D et al (2017) Mapping rice fields in Urban Shanghai, Southeast China, using sentinel-1A and landsat 8 datasets. Remote Sens 9:1-23. https://doi.org/10.3390/rs9030257

Mishra AK, Vanganuru N (2020) Monitoring a tropical super cyclone Amphan over Bay of Bengal and nearby region in May 2020. Remote Sens Appl Soc Environ 20:100408. https://doi.org/10. 1016/j.rsase.2020.100408

MoES (2021) Annual Reports 2020-2021

Mohapatra M, Mandal GS, Bandyopadhyay BK et al (2012) Classification of cyclone hazard prone districts of India. Natl Hazards 63:1601-1620. https://doi.org/10.1007/s11069-011-9891-8

Needham HF, Keim BD, Sathiaraj D (2015) A review of tropical cyclone-generated storm surges: global data sources, observations, and impacts. Rev Geophys 69:849-849. https://doi.org/10.1002/ 2014RG000477.Received

Olofsson P, Foody GM, Herold M et al (2014) Remote sensing of environment good practices for estimating area and assessing accuracy of land change. Remote Sens Environ 148:42-57. https://doi.org/ 10.1016/j.rse.2014.02.015

Palit A, Batabyal P (2010) Toxigenic Vibrio cholerae from environmental sources associated with the cholera outbreak after 'AILA' cyclone in West Bengal, India. Lett Appl Microbiol 51:241-243. https://doi.org/10.1111/j.1472-765X.2010.02873.x

Qi P, Du M (2018) Int J Appl Earth Obs Geoinformation Multi-factor evaluation indicator method for the risk assessment of atmospheric and oceanic hazard group due to the attack of tropical cyclones. Int J Appl Earth Obs Geoinf 68:1-7. https://doi.org/10. 1016/j.jag.2018.01.015

Qiu F, Berglund J, Jensen JR, Thakkar P (2004) Speckle noise reduction in SAR imagery using a local adaptive median filter speckle. Gisci Remote Sens 41:24545-25266. https://doi.org/10.2747/ 1548-1603.41.3.244

Ramsay DL, Gibberd B, Dahm J, Bell RG (2012) Defining coastal hazard zones for setback lines.A guide to good practice. Hamilton, New Zealand

Rehman S, Sahana M, Kumar P et al (2020) Assessing hazards induced vulnerability in coastal districts of India using site-specific indicators: an integrated approach Assessing hazards induced vulnerability in coastal districts of India using site-specific indicators : an integrated approach. GeoJournal. https://doi.org/10.1007/ s10708-020-10187-3 
Resio DT, Irish JL (2017) Tropical cyclone storm surge risk. Handb Coast Ocean Eng Expand Ed 2-2:1405-1422. https://doi.org/10. 1142/9789813204027_0049

Royer JF, Chauvin F, Timbal B et al (1998) A GCM study of the impact of greenhouse gas increase. Clim Chang 38:307-343. https://doi. org/10.1023/A:1005386312622

Saganeiti L, Amato F, Nolè G et al (2020) Early estimation of ground displacements and building damage after seismic events using SAR and LiDAR data: the case of the Amatrice earthquake in Central Italy, on 24th August 2016. Int J Disaster Risk Reduct. https://doi.org/10.1016/j.ijdrr.2020.101924

Saha CK (2015) Dynamics of disaster-induced risk in southwestern coastal Bangladesh: an analysis on tropical Cyclone Aila 2009. Nat Hazards 75:727-754. https://doi.org/10.1007/ s11069-014-1343-9

Sahoo B, Bhaskaran PK (2017) A comprehensive data set for tropical cyclone storm surge-induced inundation for the east coast of India. Int J Climatol 38:403-419. https://doi.org/10.1002/joc.5184

Samanta A (1997) Cyclone haxzards and community response in coastal west Bengal: an anthropo-historical perspective. Econ Polit Wkly 32:2424-2428

Schumann GJ, Moller DK (2015) Microwave remote sensing of flood inundation. Phys Chem Earth 83-84:84-95. https://doi.org/10. 1016/j.pce.2015.05.002
Torres R, Snoeij P, Geudtner D et al (2012) Remote Sensing of environment GMES Sentinel-1 mission. Remote Sens Environ 120:9-24. https://doi.org/10.1016/j.rse.2011.05.028

Tralli MD, Blom RG, Zlotnicki V et al (2005) Satellite remote sensing of earthquake, volcano, flood, landslide and coastal inundation hazards. Photogramm Remote Sens 59:185-198. https://doi.org/ 10.1016/j.isprsjprs.2005.02.002

Twele A, Cao W, Plank S et al (2016) Sentinel-1-based flood mapping : a fully automated processing chain. Int J Remote Sens 37:2990 3004. https://doi.org/10.1080/01431161.2016.1192304

Uddin K, Matin MA, Meyer FJ (2019) Operational flood mapping using multi-temporal sentinel-1 SAR images : a case study from Bangladesh. Remote Sens 11:1-19. https://doi.org/10.3390/rs111 31581

Xu H (2006) Modification of normalised difference water index ( NDWI ) to enhance open water features in remotely sensed imagery. Int J Remote Sens 27:37-41. https://doi.org/10.1080/ 01431160600589179

Zhang G, Zhang B, Yang J, He Y (2020) Monitoring of tropical cyclone structures in ten years of RADARSAT-2 SAR images. Remote Sens Environ 32:1-8. https://doi.org/10.1016/j.rse.2019.111449 